Acta vet. scand. $1967,8,14-25$.

From the Department of Biochemistry and the Department of Animal Husbandry and Genetics, Veterinary College of Norway, Oslo.

\title{
HYPOMAGNESAEMIA AND HYPOMAGNESAE- MIC TETANY INDUCED IN LACTATING COWS BY CHANGING THE DIET
}

By

Inger W. Dishington and Sverre Tollersrud

Ever since Sjollema in 1930 showed that cows suffering from grass tetany were in a hypomagnesaemic state, the question of magnesium deficiency and its causation has been the main problem in tetany research work. Although analytical investigations have shown that no magnesium deficiency is to be observed in tetany prone pasture grass, nearly all research workers agree with the theory that the magnesium absorption from this pasture is insufficient. The motivation is a lower $\mathrm{Mg}$ availability in pasture grass than in usual stall fodder. Feeding experiments performed by Kemp et al. (1961) have given support to this theory. They fed two groups of cows, one with hay, concentrates and beets in the composition generally used for stall feeding and the other with early grown pasture grass, and found a higher utilization of $\mathrm{Mg}$ in the first group. They estimated the amount of available $\mathrm{Mg}$ required for normal $\mathrm{Mg}$ balance to be at least $2.5 \mathrm{~g}$ per day for maintenance plus $0.12 \mathrm{~g}$ for each litre of milk. However, an exact amount of $\mathrm{Mg}$ needed in the diet to cover this requirement is difficult to estimate. Blaxter \& McGill (1956) suggested that $5.4 \mathrm{~g} \mathrm{Mg}$ is needed for maintenance and $1.84 \mathrm{~g}$ being sufficient to cover each gallon of milk. Bearing in mind, however, the interdependence between fodder composition and Mg availability, no exact figures can be given.

Bartlett et al. (1954) fed cows a diet containing $4.7 \mathrm{~g} \mathrm{Mg}$ per day without getting significant hypomagnesaemia, and Rook (1961, 1963) demonstrated normal serum $\mathrm{Mg}$ levels in cows as 
long as the daily Mg supply in the experimental diets amounted to 2 to $3 \mathrm{~g}$. Reduced serum $\mathrm{Mg}$ levels were not observed until the supply was reduced to $1.5 \mathrm{~g} /$ day. Serum $\mathrm{Mg}$ values as low as $0.8 \mathrm{mg}$ per cent were obtained with diets containing $0.8 \mathrm{~g} \mathrm{Mg}$ daily. Tetanic convulsions were observed only once. In tetanyprone pasture grass the serum Mg-depressing effect is obvious, despite the fact that the content of $\mathrm{Mg}$ is very seldom found to be less than 0.11 per cent of dried matter, equivalent to an intake of about $16 \mathrm{~g} \mathrm{Mg}$ a day. Consequently the $\mathrm{Mg}$ availability must be extremely low in such grass. How this comes about has been discussed for more than 30 years, but no exact conclusion has hitherto been drawn. At present, one simply has to accept the hypothesis that the first step in the development of tetany is the hypomagnesaemic condition produced by the exceptionally low availability of $\mathrm{Mg}$ in early grown, highly dressed pasture grass. The next step, however, - the outbreak of tetanic convulsions - presupposes a decrease in the serum Ca level as well, and the problem is whether this happens as an inevitable consequence of sudden reductions in the serum $\mathrm{Mg}$ level, or whether some other active compound capable of releasing the reaction is present at the same time.

In the present work the idea has been to expose high-lactating cows to sudden reductions in the dietary $\mathrm{Mg}$ from a normal level of about $25 \mathrm{~g}$ per day to a very low intake, in agreement with what possibly happens in early spring when cows are let out directly from the stall to a new-grown, highly dressed pasture. As long as reactions were observed by analyses of the serum, or clinically, the feeding was continued unchanged until possible occurrence of tetany. In those cases, however, where the falling tendency of serum $\mathrm{Mg}$ stopped, and the cows remained apparently healthy in spite of a low serum $\mathrm{Mg}$ level, oral addition of supplementary substances, possibly able to increase the tetany-prone effect of the diet, had to be given. The compounds selected for this purpose were $\mathrm{Na}_{2} \mathrm{HPO}_{4}$ and $\mathrm{Na}_{2} \mathrm{SO}_{4}$. They were tried, first and foremost because of the reduced serum Ca level observed by administering these compounds to healthy ruminants (Ender et al. 1957; Dishington 1965), but also because of the relatively high contents of alkalis, phosphorus, and sulphur found in pasture grass in which the tetany-proneness has been markedly increased by overdressings with $\left(\mathrm{NH}_{4}\right)_{2} \mathrm{SO}_{4}$ (Havre \& Dishington 1962). 


\section{MATERIAL AND METHODS}

The experiments were performed with 15 cows of the NRF breed, stalled at The Veterinary Research Station, Wöyen. They had a live weight of 405 to $600 \mathrm{~kg}$, and the milk yields varied from 12 to $21 \mathrm{~kg}$ per day. None of the cows had previously shown tetanic symptoms. The preliminary stall feeding consisted of hay, alkali-treated straw, fodder beets, and concentrates in amounts covering all requirements. 'The ration supplied the cows with 20 to $25 \mathrm{~g} \mathrm{Mg}$ per day. To make the experimental diet poor in $\mathrm{Mg}$, most of the Mg-rich compounds were replaced by wheat flour, cellulose, and whale-meat meal. Shortages on minerals and vitamins were replaced by supplements. As far as could be calculated, the nutritive value was not changed except for the reduced $\mathrm{Mg}$ content. Cows weighing $500 \mathrm{~kg}$, with a milk yield of $15 \mathrm{~kg}$ per day, received daily $15 \mathrm{~kg}$ alkali-treated straw, $5 \mathrm{~kg}$ fodder beets, $2.5 \mathrm{~kg}$ wheat flour, $2.5 \mathrm{~kg}$ fodder cellulose, $1.5 \mathrm{~kg}$ whale-meat meal, and diluted mineral acids in amounts sufficient to neutralize the excess of alkali. The vitamin requirement was covered by $A+D$ vitamin supplement, and a mineral mixture of $\mathrm{CaCO}_{3}$ and $\mathrm{Na}_{2} \mathrm{HPO}_{4}$ was given to obtain a normal dietary $\mathrm{Ca} / \mathrm{P}$ ratio. The daily ration was found to contain $9.5 \mathrm{f} . \mathrm{u} ., 1526 \mathrm{~g}$ of digestible crude protein, $55 \mathrm{~g} \mathrm{Ca}, 44 \mathrm{~g} \mathrm{P}$, and $4.8 \mathrm{~g} \mathrm{Mg}(2.55 \mathrm{~g} \mathrm{Mg}$ for maintenance $+0.15 \mathrm{~g}$ for each $\mathrm{kg}$ of milk). To minimize the risk of reduced appetite, cellulose - a rather uncommon foodstuff today - was given in advance in gradually increasing amounts; the decisive change to the Mg-deficient fodder was, however, performed abruptly. All the cows were under daily veterinary control, and blood samples for analysis were drawn at least once every day.

The experiments extended over 2 years. Seven of the 15 cows were used as test animals only once, the other 8 were used several times, interrupted by shorter or longer periods of rest. The fodder supply was calculated in proportion to the milk yield, and the appetite was under strict control. During the first days after the fodder had been changed, the cows usually refused some food, especially the cellulose. Nevertheless, there was no marked deficit in f.u. and protein intake during these days. Two tests, however, had to be terminated on the 6th day of feeding because of sudden and complete loss of appetite throughout a whole day.

Serum Mg levels showed falling tendencies in all animals. In cases where the cows tended to accomodate themselves to 
the reduced magnesium supply with a low serum $\mathrm{Mg}$ value, $\overline{\bar{\alpha}} 10 \mu \mathrm{g} / \mathrm{ml}$, the presumed trigger effect of $\mathrm{Na}_{2} \mathrm{HPO}_{4}$ or $\mathrm{Na}_{2} \mathrm{SO}_{4}$ was tried. Relatively high oral doses of these compounds - viz. $125 \mathrm{~g}$ - were given twice with 1 hour's interval without changing the fodder.

\section{RESULTS}

A survey of all experiments is presented in Tables 1 and 2. Section 1 deals with 15 experiments carried out with cows that had not been test animals before, and are demonstrated in Table 1. A review of the 20 repeated experiments, section 2 , is presented in Table 2.

\section{Comments to Table 1}

All 15 cows in the first experiment reacted acutely to the Mg-deficient feeding with decreases in the serum $\mathrm{Mg}$ level. The decreasing rate varied; but, except for $1 \mathrm{cow}$, whose serum $\mathrm{Mg}$ stopped dropping at a level of $13 \mu \mathrm{g} / \mathrm{ml}$, they all reached $10 \mu \mathrm{g} / \mathrm{ml}$ or lower values within 2 to 18 days. By continued feeding only the two cows Songfryd and Anne got tetany. Songfryd was fed the experimental diet for 4 days when she collapsed in tetany. The serum Mg value fell exceptionally rapidly and a decreasing tendency was observed in the serum Ca level already within 2 days. Her appetite was good until she collapsed. Anne, a cow in her first lactation with high yields, was used as a test animal as early as one month after parturition. She had been exposed to the experimental diet for 7 days when she contracted tetany. To what extent the condition could be attributed to the Mg-deficient fodder per se is, however, difficult to judge, because the cow developed a total loss of appetite and was taken out of the experiment the day before she collapsed.

Holdis was in the same experimental group as Anne. For some unknown reason she also suddenly refused to eat and was removed from the experiment the following day. She, however, began to eat again as soon as the fodder was changed to normal, and remained healthy.

The other 12 cows had a good appetite and were clinically healthy despite the pronounced hypomagnesaemia as long as the experimental fodder was given.

In 10 cases oral $\mathrm{Na}_{2} \mathrm{HPO}_{4}$ supplementation was tried: Sonni, Seiergod, Krone, Ase, and Ragnlin reacted to the dosing with 


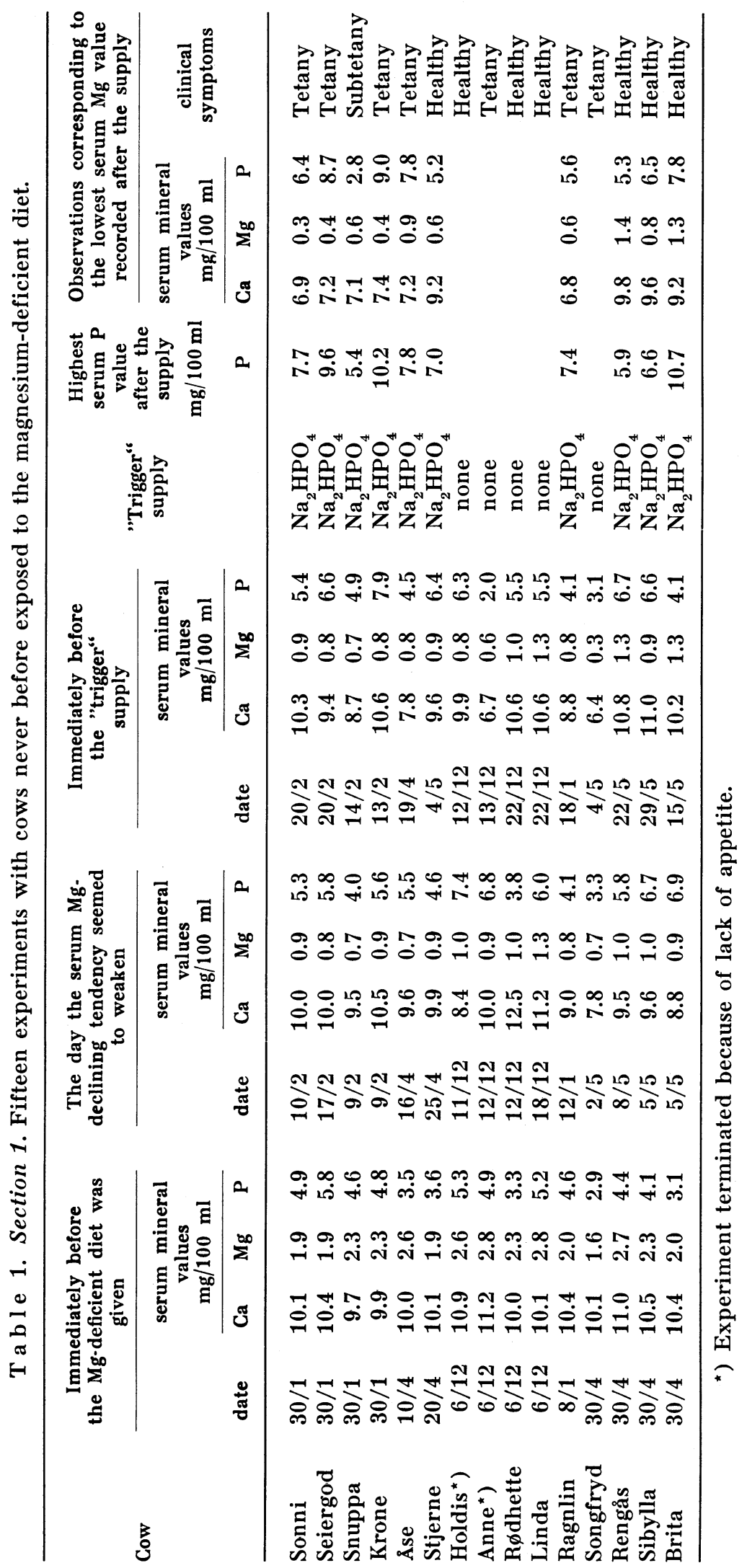


spontaneous decreases in serum Ca followed by tetanic convulsions. They had been hypomagnesaemic for 10, 3, 4, 3, and 6 days, respectively, when the supplement was given. Krone was the most seriously affected and died despite treatments with calcium gluconate and magnesium chloride. The others, however, recovered after treatment and transfer to normal feeding supplemented with MgO. Snuppa, who got $\mathrm{Na}_{2} \mathrm{HPO}_{4}$ on the 5th day of hypomagnesaemia, reacted with clinical symptoms of subtetany. Stjerne and Sibylla received the "trigger" supplies on the 9 th and 24th days, respectively, of hypomagnesaemia, but remained clinically unaffected even though some further decreases in the serum $\mathrm{Mg}$ levels occurred. Rengås and Brita did not react to the supplies at all. These 2 cows had, to some extent, been able to raise their serum $\mathrm{Mg}$ levels again during the feeding period, and this increasing tendency before dosing might perhaps have been the reason that the "trigger" supply had no influence. Individual susceptibility might, however, also play an important part in these experiments.

\section{Comments to Table 2}

In all 20 repeated experiments the serum $\mathrm{Mg}$ level dropped to hypomagnesaemic values, about $10 \mu \mathrm{g} / \mathrm{ml}$, within 3 to 18 days of $\mathrm{Mg}$ deficient feeding. Prolonged feeding resulted in 3 cases of tetany: Sonni collapsed in her third experiment and $\AA s e$ in her first and third experiment. In 17 cases the cows remained healthy on a very low serum $\mathrm{Mg}$ level. By abrupt oral administration of $\mathrm{Na}_{2} \mathrm{HPO}_{4}, \mathrm{Na}_{2} \mathrm{SO}_{4}$, or both to the hypomagnesaemic cows in 15 cases, 11 distinct reactions were observed. Convulsions appeared in 4 cases: Sonni collapsed after supplementation in her 5th experiment, $A s e$ in her third, and Holdis in her second and third experiment. Subtetanic convulsions were observed in 3 cases: the second experiment with Sonni and both experiments carried out with Seiergod. Slighter reaction with borderline symptoms were observed in 4 cases: the first experiment with Sonni, the first with Snuppa, the first with Holdis, and the only repeated experiment with Linda. In 4 cases the supply had no influence.

\section{Conclusion}

Thirty-five feeding experiments were carried out to demonstrate the reaction of relatively high lactating cows to sudden reductions in the daily dietary $\mathrm{Mg}$ supply. The reduction was 


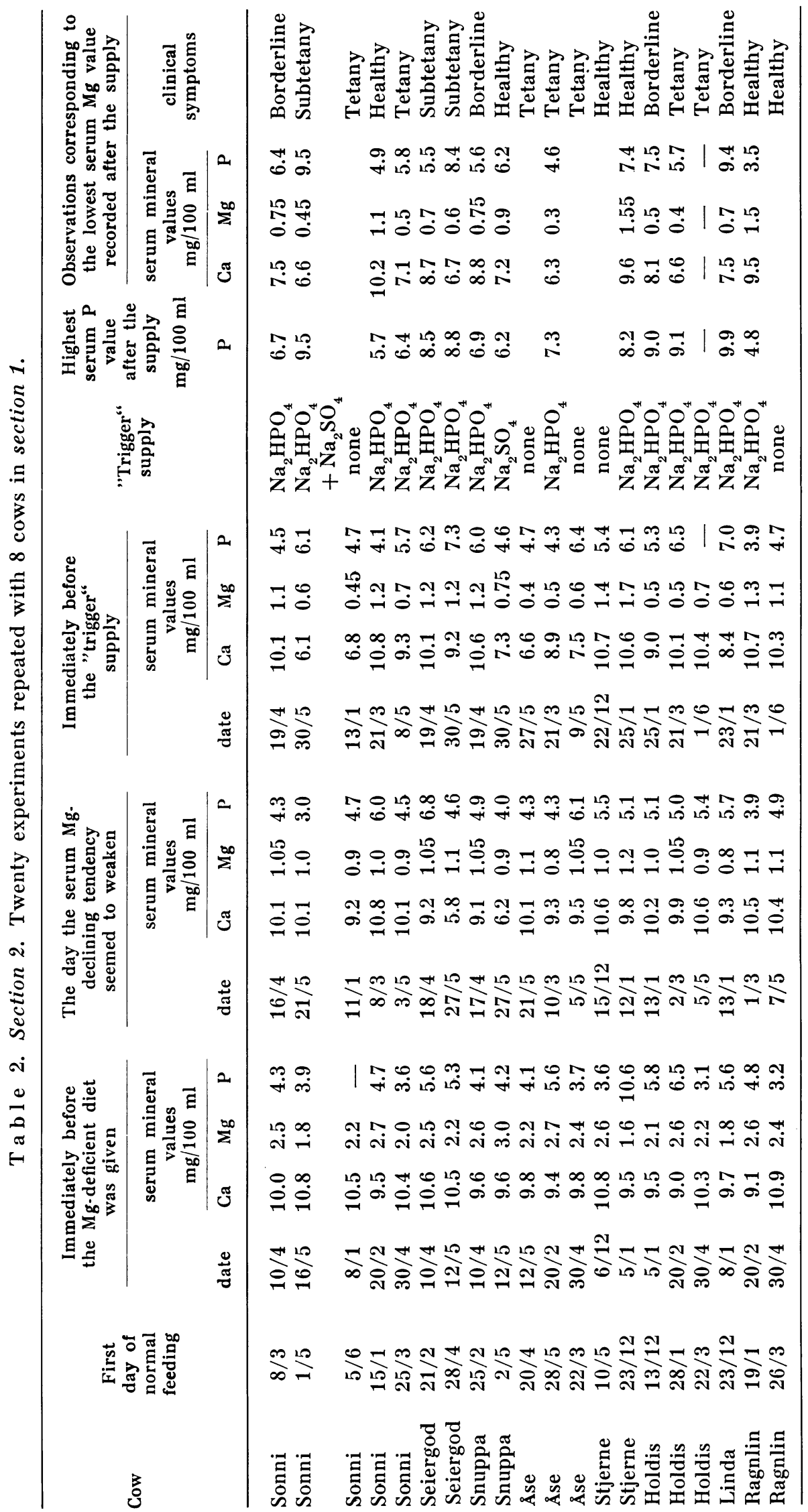


made from a normal level of $25 \mathrm{~g} \mathrm{Mg}$ per day to 4.3 to $5.6 \mathrm{~g} \mathrm{Mg}$ per day proportional to the milk yield. This reduction produced pronounced hypomagnesaemic serum $\mathrm{Mg}$ values within 2 to 18 days in all experiments. Continued $\mathrm{Mg}$-deficient feeding resulted in tetany in 5 cases, whereas 30 remained clinically healthy in spite of a marked hypomagnesaemia. Oral doses of $\mathrm{Na}_{2} \mathrm{HPO}_{4}, \mathrm{Na}_{2} \mathrm{SO}_{4}$ or both given to 25 hypomagnesaemic cows resulted in 9 cases of tetany, 4 cases of subtetany, and 4 cases of slighter borderline symptoms. In 8 cases the cows remained unaffected.

\section{DISCUSSION}

The instantaneous effect of an abrupt reduced dietary $\mathrm{Mg}$ supply upon the serum $\mathrm{Mg}$ level obtained in these experiments indicates clearly that the cows had not been able to deposit available magnesium, even though the preliminary feeding was rich in this mineral. Very likely this inability is a general phenomenon in ruminants, and has to be looked upon as the main reason why they cannot obtain a normal $\mathrm{Mg}$ metabolism, even for shorter periods, without having access to an even flow of magnesium. To state the exact minimum of $\mathrm{Mg}$ required in the diet to avoid hypomagnesaemia seems to be impossible. The amount of dietary $\mathrm{Mg}$ available for absorption is not dependent merely upon the exact content of $\mathrm{Mg}$ in the diet, but just as much upon the dietary composition in other respects. The diet described by Rook (1961, 1963) did not influence the serum $\mathrm{Mg}$ level as long as the $\mathrm{Mg}$ content was above $1.5 \mathrm{~g}$ per day, and the experiments carried out by Allcroft \& Parr (Bartlett et al. 1954) showed that a total support of 4 to $7 \mathrm{~g} \mathrm{Mg}$ per day in the diet was sufficient to maintain normal serum $\mathrm{Mg}$ values. The diet used in the experiments described in this paper had, however, a marked serum Mg-reducing influence with a dietary $\mathrm{Mg}$ content calculated to 4.3 to $5.6 \mathrm{~g}$ per day. As to the severity of hypomagnesaemia and risk of tetany, however, the individual disposition seems to play an important part.

The experiments described were made as a part of the study of tetany in cattle, and the abrupt reduction in dietary $\mathrm{Mg}$ was performed to duplicate as closely as possible what seems to happen when the cows are exposed to tetany-prone pastures in the spring. The 5 cases of tetany provoked by no other influence than the Mg-deficient diet seem to indicate that the sudden reduction in $\mathrm{Mg}$ availability that occurs when cows are fed a 
new-grown pasture could perhaps, under unfavourable conditions, be a releasing factor per se. The 30 other cases, in which the cows remained apparently healthy despite typical hypomagnesaemic serum values, prove, however, that cows are generally able to withstand relatively severe decreases in available dietary $\mathrm{Mg}$ without being attacked by tetany as long as other factors are not involved. Nevertheless, the disposition to illness is undoubtedly markedly increased when the serum $\mathrm{Mg}$ level is low, and it seems obvious that a major step towards tetany is made. In this situation avoidance of the disease merely depends upon the maintenance of an undisturbed serum Ca balance. According to analytical examinations of $\left(\mathrm{NH}_{4}\right)_{2} \mathrm{SO}_{4}$ dressed tetanyprone grass and dosing experiments carried out with healthy ruminants, we have in earlier papers pointed to alkalis, phosphates, and sulphates as the dietary compounds most likely to disturb this balance. In the present experiments the same compounds are given as supplements to already hypomagnesaemic cows. The clinical reactions observed in 17 out of 25 experiments made it evident that these compounds, when present in excess as in the $\left(\mathrm{NH}_{4}\right)_{2} \mathrm{SO}_{4}$ dressed pasture grass, undoubtedly have to be taken into account as factors contributing to tetany attacks.

\section{ACKNOWLEDGMENT}

The authors wish to thank Professor Fredrik Ender and Professor Per Slagsvold for their interest and good advice in this work.

\section{REFERENGES}

Bartlett, S., B. B. Brown, A. S. Foot, S. J. Rowland, R. Allcroft \& W. H. Parr: The influence of fertilizer treatment of grassland on the incidence of hypomagnesaemia in milking cows. Brit. vet. J. 1954, 110, 3-19.

Blaxter, K. L.\& R. F. McGill: Magnesium metabolism in cattle. Vet. Rev. Annot. 1956, 2, 35-55.

Dishington, I. W.: Changes in serum magnesium levels of ruminants, as influenced by abrupt changes in the composition of the diet. Acta vet. scand. 1965, 6, 150-177.

Ender, F., I. W. Dishington \& A. Helgebostad: The magnesium problem in relation to the tetany paresis syndrome in dairy cows. Nord. Vet.-Med. 1957, 9, 881-917.

Havre, G. N. \& I. W. Dishington: The mineral composition of pasture as influenced by various types of heavy nitrogen dressings. Acta agric. scand. 1962, 12, 298-308. 
Kemp, A., W. B. Deijs, O. H. Hemkes \& A. J. H. van Es: Hypomagnesaemia in milking cows: intake and utilization of magnesium from herbage by lactating cows. Neth. J. agric. Sci. 1961, 9, $134-149$.

Rook, J. A. F.: Rapid development of hypomagnesaemia in lactating cows given artificial rations low in magnesium. Nature (Lond.) 1961, 191, 1019.

Rook, J.A.F.: Experimental magnesium deficiency in the cow. J. comp. Path. 1963, 73, 93-97.

Sjollema, B.: On the nature and therapy of grass staggers. Vet. Rec. $1930,10,425-430,450-453$.

\section{SUMMARY}

Thirty-five experiments are demonstrated in which high-lactating cows were exposed to abrupt changes from a normal dietary Mg supply to an extremely $\mathrm{Mg}$-poor diet. The preliminary diet was adequate, supplying the cows with about $25 \mathrm{~g} \mathrm{Mg}$ per day. The experimental feeding was individually calculated, containing $2.55 \mathrm{Mg}$ for maintenance and $0.15 \mathrm{~g}$ for each $\mathrm{kg}$ of milk. Daily serum mineral analyses showed a pronounced hypomagnesaemia in all 35 experiments within 2 to 18 days. In 5 experiments there was a simultaneous fall in serum Ca, and the cows collapsed in tetany. The other 30 cases remained clinically healthy in spite of the low serum $\mathrm{Mg}$ level as long as the diet was given unchanged. In 25 cases these already hypomagnesaemic cows were exposed to a relatively high oral supplementation of $\mathrm{Na}_{2} \mathrm{HPO}_{4}, \mathrm{Na}_{2} \mathrm{SO}_{4}$ or both. In 9 cases the supply led to pronounced tetanic convulsions, in 4 cases a subtetanic state was observed, and in 4 cases the cows showed borderline symptoms, i.e., they reacted clinically as well as analytically immediately after the supply was given, but no attacks appeared, and the cows recovered as soon as normal fodder was given. In 8 cases the cows did not react to the "trigger" doses at all.

The experiments are discussed and the reactions compared with those observed when high-lactating cows are let out on tetany-prone, $\left(\mathrm{NH}_{4}\right)_{2} \mathrm{SO}_{4}$-dressed pastures. The conclusion is drawn that a high $\mathrm{Mg}$ content in the diet prior to a Mg-deficient diet has little, if any, influence on the tendency to precipitate tetany. Considerable decreases in content, or availability, of dietary $\mathrm{Mg}$ always lead to decreases in serum Mg. Occasionally, under special unfavourable circumstances, when the drop in serum $\mathrm{Mg}$ is extraordinary rapid, the serum Ca level may drop as well and tetany occur without further stressing elements. In most cases, however, the results seem to support the suggestion that tetanic couvulsions are not conditioned entirely by the reduced availability of $\mathrm{Mg}$ but are to a great extent dependent upon the serum Ca-reducing effect of co-operating, so-called trigger compounds, simultaneously present in the diet. In this connection the addition of $\mathrm{Na}_{2} \mathrm{HPO}_{4}$ and $\mathrm{Na}_{2} \mathrm{SO}_{4}$ to the $\mathrm{Mg}$-poor diet has been studied and found to confirm the suggestion made in earlier papers (Ender et al. 1957; 
Dishington 1965) that the high content of $\mathrm{Na}, \mathrm{K}, \mathrm{P}$, and $\mathrm{S}$ found in $\left(\mathrm{NH}_{4}\right)_{2} \mathrm{SO}_{4}$-dressed pasture grass seems to play a prominent part in making this grass tetany-prone.

\section{ZUSAMMENFASSUNG}

Hypomagnesaemie und hypomagnesaemische Tetanie bei melkenden Kühen hervorgerufen durch eine Futteränderung.

Fünfunddreissig Versuche, in welchen hochleistende Milchkühe einer plötzlichen Futteränderung von normal Mg-haltigem Futter zu ausgesprochen Mg-armen Futter ausgesetzt wurden, werden beschrieben. Allen Kühen wurde dasselbe Normalfutter verabreicht. Dieses enthielt $25 \mathrm{~g} \mathrm{Mg}$ pro Tagesration, während das Versuchsfutter individuell berechnet wurde und nur 2,55 g Mg zum Erhalt erhielt $+0,15 \mathrm{~g}$ pro $\mathrm{kg}$ Milch. Tägliche Serummineral-Analysen zeigten einen deutlichen Fall im Serum-Mg-Spiegel und einen ausgesprochen hypomagnesaemischen Zustand in allen 35 Versuchen nach 2 bis 18 Tagen. In 5 Fällen zeigten ebenfalls die Serum-Ca-Werte schon im Laufe von wenigen Tagen eine fallende Tendenz mit einer ausgesprochenen Tetanie zufolge. In 30 Versuchen waren die Kühe weiterhin lebhaft trotz der sehr niedrigen Serum-Mg-Werte, so lange das Futter unverändert verabreicht wurde. In 25 Versuchen wurden den anscheinend gesunden aber hypomagnesaemischen Kühen plötzlich relativ grosse orale Zuschüsse von entweder $\mathrm{Na}_{2} \mathrm{HPO}_{4}$ oder $\mathrm{Na}_{2} \mathrm{SO}_{4}$ oder von beiden Stoffen verabreicht. Diese Zuschüsse hatten in 9 Versuchen typische Tetanieausbrüche zufolge und in 4 Versuchen wurde bei den Tieren ein subtetanischer Zustand festgestellt. In weiteren 4 Versuchen gab der Zuschuss eine deutliche Reaktion. Der Krampf blieb jedoch aus und die Kühe erholten sich ohne Behandlung. In 8 Fällen wurde keine Reaktion auf den Zuschuss registriert.

Das Forschungsprogramm sowie die Ergebnisse werden diskutiert und mit der Zusammensetzung des Futters und den Reaktionen der Kühe auf stark $\left(\mathrm{NH}_{4}\right)_{2} \mathrm{SO}_{4}$-gedüngten Tetanieweiden verglichen. Die Versuchsergebnisse zeigen, dass das Speicherungsvermögen der Kühe was zugängliches $\mathrm{Mg}$ betrifft minimal ist. Ein grosser Überschuss von $\mathrm{Mg}$ im Futter vor der Futteränderung oder vor dem Auslassen auf die Weide hat geringen oder gar keinen Einfluss, wenn das neue Futter tetaniehervorrufend ist. Futter, welches Mg-Mangel oder herabgesetzte Möglichkeiten für eine Mg-Aufnahme bewirkt, wird immer einen Fall im Serum-Mg-Spiegel hervorrufen. In einzelnen Fällen unter besonders ungünstigen Umständen, wo der Serum-Mg-Gehalt besonders schnell herabsinkt, kann das Serum-Ca-Niveau ebenfalls gestört werden und eine Tetanie ohne weiteren äusseren Anlass hervorrufen. In den meisten Fällen lassen die Ergebnisse jedoch vermuten, dass der Tetanieausbruch nicht nur durch eine herabgesetzte Mg-Aufnahme sondern auch durch die Anwesenheit von „Trigger"-Stoffen bedingt ist. Auf den positiven Einfluss der Beigabe von $\mathrm{Na}_{2} \mathrm{HPO}_{4}$ oder $\mathrm{Na}_{2} \mathrm{HPO}_{4}$ $+\mathrm{Na}_{2} \mathrm{SO}_{4}$ wird hingewiesen als eine Unterstützung der früher hervorgesetzten Theorie (Ender et al. 1957; Dishington 1964). Infolge 
dieser Theorie trägt der grosse Überschuss an $\mathrm{K}, \mathrm{Na}, \mathrm{P}$ und $\mathrm{S}$, welcher in stark ammonsulphatgedüngten Weidegras vorhanden ist, bedeutend dazu bei, dass Tetanie auf diesen Weiden so häufig auftritt.

\section{SAMMENDRAG \\ Hypomagnesemi og hypomagnesemisk tetani fremkalt hos melkekyr ved fóromlegning.}

Det er beskrevet 35 fors $\varnothing \mathrm{k}$ hvor høytytende melkekyr har vært utsatt for en plutselig fôromlegning fra fôr med normalt $\mathrm{Mg}$ innhold til et utpreget $\mathrm{Mg}$ fattig fôr. Normalfôret var det samme for alle kuene og inneholdt $25 \mathrm{~g} \mathrm{Mg}$ pr. dagsrasjon, mens det eksperimentelle fôret var individuelt beregnet og inneholdt bare $2,55 \mathrm{~g} \mathrm{Mg}$ til vedlikehold $+0,15 \mathrm{~g}$ til hver kg melk. Daglige serum-mineral-analyser viste et tydelig fall i serum Mg-speilet, og en utpreget hypomagnesemisk tilstand $\mathrm{i}$ alle 35 fors $\varnothing \mathrm{k}$ etter $2-18 \mathrm{~d} \phi \mathrm{gn}$. I 5 tilfeller viste også serum Ca-verdien fallende tendens allerede etter få dager, og kuene fikk tydelig tetani. I 30 fors $\varnothing \mathrm{k}$ var kuene fortsatt friske til tross for meget lave serum $\mathrm{Mg}$ verdier så lenge fôret ble gitt uforandret. I 25 fors $\varnothing \mathrm{k}$ ble disse friske, men hypomagnesemiske kuene utsatt for plutselige, relativt store, orale tilskudd av $\mathrm{Na}_{2} \mathrm{HPO}_{4}, \mathrm{Na}_{2} \mathrm{SO}_{4}$ eller begge. I 9 fors $\phi \mathrm{k}$ resulterte tilskuddet i typiske tetaniutbrudd og i 4 fors $\varnothing \mathrm{k}$ ble det observert en subtetanisk tilstand hos dyrene. Fire fors $\varnothing \mathrm{k}$ ga tydelig reaksjon etter støtet, men krampen uteble og kuene kom seg uten behandling. I 8 tilfelle ble det ikke registrert noen reaksjon på støtet.

Opplegg og resultater er diskutert og sammenlignet med fôrets sammensetning og kuenes reaksjoner på sterkt $\left(\mathrm{NH}_{4}\right)_{2} \mathrm{SO}_{4}$-gjødslete tetanibeiter. Fors $\varnothing$ ksresultatene viser at kuenes evne til å lagre tilgjengelig $\mathrm{Mg}$ er minimal. Et stort overskudd av $\mathrm{Mg}$ i fôret $\mathrm{f} \emptyset \mathrm{r}$ omlegning eller f $\varnothing \mathbf{r}$ beiteslipp, har liten eller ingen innflytelse hvis det nye fôret er tetanifrembringende. Fôr som gir Mg-underskudd eller nedsatte muligheter for Mg-oppsugning, vil alltid gi fall i serum Mg-speilet. I enkelte tilfelle, under særlig uheldige omstendigheter når serum Mg-innholdet faller særlig raskt, kan også serum Ca-nivået bli forstyrret og tetani bryte ut uten annen ytre påvirkning, men $i$ de fleste tilfelle synes resultatene å tyde på at ikke bare nedsatt Mg-oppsugning, men også tilstedeværelse av „trigger"-stoffer er en betingelse for tetaniutbrudd. Det positive utslag som er funnet ved tilskudd av $\mathrm{Na}_{2} \mathrm{HPO}_{4}$ eller $\mathrm{Na}_{2} \mathrm{HPO}_{4}+\mathrm{Na}_{2} \mathrm{SO}_{4}$ er blitt pekt på som en st $\varnothing t$ te for en allerede tidligere fremsatt teori (Ender et al. 1957; Dishington 1964), om at det store overskudd av K, Na, P og S, som er tilstede i sterkt ammonsulfatgjødslet beitegras, må antas å være en betydelig medvirkende årsak til at tetani er så utbredt på disse beitene.

(Received August 3, 1966). 